2. Kovalev S.I. Istoriya Rima [History of Rome]. L. : LGU, 1986. 807 c. [in Russ.]

3. Kolosovskaya YU. K. Rim i mir plemen na Dunaye. I-IV vv. n.e. [Rome and the world of tribes on the Danube. I-IV centuries AD] M. : Nauka, 2000. 288 s. [in Russ.]

4. Kornyushina R. V. Zarubezhnyy opyt sotsial'noy raboty [Foreign experience of social work]. Vladivostok : Izd-vo Dal'nevost. un-ta, 2004. 84 s. [in Russ.]

5. Gerber D. Disabled veterans in history. USA: The University of Michigan press, 2000. $410 \mathrm{p}$. [in Eng.]

6. Istoriya stran Tsentral'noy i Yugo-Vostochnoy Yevropy XX veka [History of the countries of Central and Southeast Europe of the XX century]: ucheb. posobiye ; pod red. A.V. Fadeyeva. M. : Profizdat, 1997. 350 s. [in Russ.]

7. Zoriktuyeva A.V. Zarubezhnyy opyt gosudarstvennoy zashchity veteranov boyevykh deystviy (istoriko-politologicheskiy aspekt) [Foreign experience of state protection of war veterans (historical and political aspect)]. Vestn. Vostochno-Sibirskogo gos. tekhn. un-ta. 2011. Vyp. 1. s. 131-136. [in Russ.]

8. Lebedeva L. F. SShA: Gosudarstvo i sotsial'naya politika [USA: Government and social policy]. M.: Nauka, 2007. 271 s. [in Russ.]

9. Popov A. My postupim mudro: my s vami ne budem borot'sya. My prosto - ne poydom za vami [We will act wisely: we will not fight with you. We are just not going to follow you]. URL: http://popovandrey.livejournal.com/57101.html. [in Russ.]

\title{
Summary
}

This article deals with formation and development history of the social and legal guarantee providing system as to the hostility participants, taking into consideration Great Britain, France, Germany and the United States of America experience up to 1914. These countries were not chosen by chance. The selection criterion was military activity, which was more than high in comparison with other states due to the colonial empire statuses. The USA, however, was taken as a state formed precisely in the fight against colonialism. Clear interdependence of the study subject, above mentioned countries army participation in the hostilities and welldefined state guaranteed socio-economic orientation to veterans were revealed. The explanation of the state structures efforts to reduce their own social burden in the category specified form and, at the same time, little attention to the social and psychological adaptation after war were taken into consideration.

Keywords: protection of motherland, veterans, social and legal guarantee, a system of social guarantees, law, war.

UDC 34:336.77:63:332.3 (477):94 (470«312»)

DOI: $10.31733 / 2078-3566-2019-5-105-113$

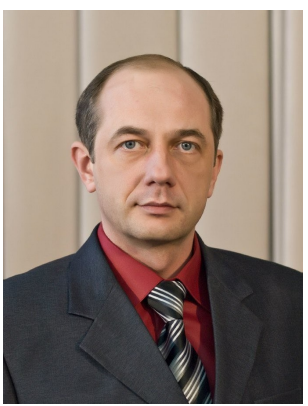

Dmytro SELIKHOV ${ }^{\complement}$

Ph.D

(Dnipropetrovsk State University of Internal Affairs)

\section{SOURCE BASE OF LEGISLATIVE REGULATION OF AGRICULTURAL CREDIT ON THE UKRAINIAN LANDS OF THE RUSSIAN EMPIRE (second half of XIX - early XX century)}

ДМИтро СеЛіхов. ДЖЕРЕЛЬНА БАЗА ЗАКОНОДАВЧОГО РЕГУЛЮВАННЯ СІЛЬКОГОСПОДАРСЬКОГО КРЕДИТУ НА УКРАЇНСЬКИХ ЗЕМЛЯХ РОСІЙСЬКОӤ IMПЕРІЇ (друга половина XIX - початок XX ст.) Аграрний сектор сучасної України знаходиться на тому етапі свого реформування, коли процес регулювання суспільних відносин у сфері виробництва і збуту сільськогосподарської продукції на законодавчому рівні близький до свого логічного завершення, адже переважна частина депутатів Верховної Ради України налаштована ухвалити врешті-решт закон про обіг земель сільськогосподарського призначення, який має відкрити нову сторінку розвитку вітчизняного аграрного ринку. 3 цієї позиції не лише теоретичний, а й практичний інтерес викликають питання, пов'язані вивченням того історичного досвіду законодавчого регулювання іпотечного кредиту, який мав місце у нашій країні після скасування у 1861 році кріпосного права та здійснення інших реформ аграрного сектору економіки України у другій половині XIX і на початку XX ст. Основна увага у даній публікації зосереджена на аналізі кредитного законодавства у його різноманітніших формах, які побутували у період, що

(C) Selikhov D., 2019

ORCID iD: https://orcid.org/0000-0003-2180-1010

dmitriy.selihov1969@gmail.com 
вивчається. Маємо на увазі різноманітні «Укази», «Положення», «Правила», «Думки», «Інструкції» тощо. Зважаючи на те, що центральною віссю земельного кредиту на рубежі XIX-XX ст. було законодавство щодо діяльності державних банків, природно, що саме вони (Селянський поземельний та Дворянський земельний банк) стали предметом пильної уваги автора. Звідси і характеристика таких правових актів як «Про порядок продажу з торгів земельних ділянок, заставлених у Селянському поземельному банку», «Про дозвіл Селянському поземельному банку на видачу позик для купівлі земель, які не належали до селянського стану землевласниками деяких повітів Херсонської і Подільської губерній», «Про затвердження Державного дворянського земельного банку», «Про розповсюдження на позичальників приватних земельних банків пільг, встановлених Положенням про Державний дворянський земельний банк» тощо. Поряд зі згаданими вище правовими актами, які зосереджені переважно у «Полном собрании законов Российской империи» (видання друге та третє), у статті згадано також такі джерела щодо змісту і форми сільськогосподарського кредиту 1861-1917 років, як газета «Правительственный вестник», та журнали «Вестник финансов, промышленности и торговли», «Вестник мелкого кредита», у яких відображені практичні заходи щодо реалізації тих чи інших законодавчих актів та ролі у цьому процесі місцевих державних адміністрацій і земства.

Ключові слова: Російська імперія, Украӥна, законодавство, сільськогосподарський кредит.

Formulation of the problem. The level of any historical and legal research depends to a great (if not decisively) extent on the presence, completeness and availability of the relevant sources. A researcher of the history of the state and law of the Russian Empire of the nineteenth and twentieth centuries in general and its individual regions, in particular, will not be able to complain about their deficits. On the contrary, the range of such sources is extremely wide, which creates some difficulties at the stage of determining, relatively speaking, the main and secondary, that is, such sources, which can be avoided without damaging the quality of the subject of research.

Analysis of recent research and publications. The abovementioned is directly related to many problems of the domestic history of the era of free entrepreneurship, which, according to some researchers, came after the abolition of serfdom in 1861, including the issues of legislative regulation of agricultural credit. This topic has already received some coverage in the historical and legal literature. In particular, it was analyzed in his thorough monograph on the institutions of long-term credit in the Russian Empire by legal expert V.Y. Kirichenko [29]. The characteristic of legislative regulation of banking activity was carried out in the dissertations of D.A. Pashentsev [33] and O.E. Finogentov [40], publications by O.M.Holovko [25], A.P. Korelin [30], V.S. Dyakin [26] and other researchers of the national history of the late XIX - early XX centuries.

The purpose of the article: to analyze the source of legislative regulation of all major types of agricultural credit in the Ukrainian lands of the abovementioned historical period.

Basic content. For obvious reasons, the main source of research on the topic of interest to us is the "Complete Collection of Laws of the Russian Empire". It consists of three editions. As the first to absorb the legislative of Tsarist of Russia in the period 1649-1825, the second from 1825 to 1881 . The third, in which, in fact, the main legislative acts concerning certain credit issues of the end of the XIX - beginning of the XX century cover the period from March of 1881 to 1915 . It is important to note that in the tsarist legislation of the second half of the nineteenth and early twentieth centuries there were various types of legislation, such as: laws (including the Basic Laws), emergency laws, decrees, manifests, regulations, scripts, rules, instructions, clarifications, and some others. In addition, one should distinguish between the concept of law as a general legal category and law as some form of legislative acts. Some legal scholars understand the notion of "law" as a manifestation of the "will of the classes that have won and hold public treason" [31, p. 285]. A similar interpretation of the term in the system of imperial legislation is found in such well-known modern legal scholars as V.E. Kirichenko and O.M. Holovko [24]. No country in the world had as many laws as in tsarist Russia. According to Art. 53 of the Basic Laws, any legal act approved by the king was considered a law [36]. According to Art. 53 of the Basic Laws, any legal act approved by the tsar was considered a law [36]. It turns out that the law was "Credit Charter", as the basis for the operation of any credit institutions [39], as well as various "Decrees", "Regulations", "Rules", "Dumkas", "Instructions", etc., which regulated specific problems with lending to agricultural producers by banks, zemstvos, cooperatives and other institutions or organizations. Thus, in the form of decrees were published such legal acts as "On reducing payments to borrowers of the Peasant Land Bank" [38], "On granting loans to the Peasant Land Bank secured by pledged land" [23], "On facilitating the tasks of the Peasant Land Bank for assistance to expanding the area of land 
ownership of small land "[22]," On the reduction of payments to borrowers of the Peasant Land Bank and changing the terms of issuance of state certificates of the overmentioned bank "[21]. However, most legal acts concerning the conditions of crediting of agricultural producers were published in the form of various "Regulations". It is under this concept that legal acts such as "On extending privileges to borrowers of private land banks established by the Regulations on the State Noble Land Bank" [12] came into force; "On Measures for Restoration of Kharkiv Land Bank Activity» [11]; "On the exclusion of hostile subjects from the members of the $\mathrm{Mu}$ tual Credit Society and City Credit Societies" [1]. There were also legal acts that were published under the original name, such as "Dumka". These included the following documents: "On the procedure for the execution of serfs on the purchase of land purchased with the assistance of a land bank" [4], "On changes and additions to the current rules on the opening of new joint-stock commercial banks", "On the procedure for sale from auctions of land pledged in the Peasant Land Bank "[5], "On allowing the Peasant Land Bank to issue loans for the purchase of land not belonging to the peasant state to the landowners of certain counties of Kherson and Podilsky Regions [10], "On approval of the State Noble Land Bank" [9], "On the publication of rules on peasant land associations that bought land with the assistance of the Peasant Land Bank" [6], "On changing the order of audit of public credit institutions" [8], "On measures for timely payment to the Peasant Land Bank" [3], "On permitting long-term credit institutions to extinguish mortgage letters and bonds through both circulation and purchase at the exchange" [2]. Without defining of the form of a legislative act, legal acts on the statutes of state and joint-stock land banks were published, such as: "Charter of the Land Bank of Kherson Province" [14], "Charter of the Land Credit Society" [18], "Charter of the Mutual Land Credit Society" [17], Statutes of Kherson Land Bank [14], Kharkiv [6], Poltava [19] and Kyiv [15] joint stock and state - Peasant [16] and Noble [13] land banks. Taking into account the problems that arose during the implementation of the statutes of a bank, the government has made changes necessary to their content. This was also reflected in the relevant legal acts, which were published either in the form of "Regulations" [33], "Dumkas" or "Decrees" (as discussed above), or simply as certain changes to certain paragraphs of the statute [32].

It should be noted that the multivolume editions of the Full Law of the Russian Empire were printed in the Senate printing house. The first edition was designed as a legal memorial and as a guide to legal and executive activity for state chambers and provincial governments, and therefore had an appropriate target inscription at the beginning of each volume, such as «Kharkiv State Chamber».

The second edition was printed in a much larger circulation and had little target inscriptions. These legal acts were obligatory received by the provincial chief courts and offices of governors and governors-general. The second edition was printed in a much larger circulation and had little target inscriptions. These legal acts were obligatory received by the provincial chief courts and offices of governors and governors-general. Although the published legislation did not reflect the whole palette of transient social relations, they did, to a certain extent, reflect the natural course of social development and were conditioned by the subjective factors of those who determined their continued participation in the process of writing. On the whole, there is no doubt that the legislative acts only recorded the results of certain social processes. They do not make it possible to accurately trace the trend of the tsarist power policy, however, serving as a basis for explaining many of its aspects in various fields, including, of course, such as agricultural credit. Legislative preparation and implementation depended on the court environment, its political and economic interests, personal likes and dislikes, informal relationships, including so-called corruption. Legislative preparation and implementation depended on the court environment, its political and economic interests, personal likes and dislikes, informal relationships, including so-called corruption. The main functions related to the implementation of both published and unpublished (were and such) legislative acts were entrusted to regional structures of state power (offices of governors-general, governors), which in their activity were guided not so much by law as by political expediency. tasks assigned to them personally by the emperor. Thus, for the researcher of the history of the state and law of the Russian Empire in the second half of the nineteenth and early twentieth centuries, the legislative acts constitute a historical and legal source for studying the mechanism of public policy implementation in a particular sphere of life of society, but they are not, regardless of their informative saturation, to recreate all its directions and nuances. In order to get the fullest possible picture of the course of events on certain issues of internal policy, the researcher should refer to the records, part of which was published both for internal use and for informing the general public. The 
latter include, for example, publications such as the Journals of Provincial Presences. Thus, in the journal of Poltava provincial presence for July-August 1907 published "Rules for granting loans to the Peasant Land Bank to improve land use" [34]. The latter include, for example, publications such as the Journals of Provincial Presences. Thus, in the journal of Poltava provincial presence for July-August 1907 published "Rules for granting loans to the Peasant Land Bank to improve land use" [34]. In particular, they referred to the implementation of the royal decree of November 15, 1906 [28]. These rules, as evidenced by their text, were a kind of annex to item \# 3 of article \# 7 of the famous decree of November 9, 1906 [28]. The Instruction established a specific procedure for issuing loans for "land improvement": according to it, the peasants could count on the loan provided: b) in the case of community displacement into separate villages or farms; c) in the distribution of allotment land belonging to the community into cutting areas; d) when taken to one place through striped areas of individual households."

Those who applied for the loan for the local branch of the Peasant Bank. If they were in compliance with the law, the bank had to obtain the consent to issue a loan to the county land management commission. If, for some reason, the county commission did not give its consent to the credit of the Peasant Bank, the client could have appealed its decision to the provincial land management commission, the decision of which was considered final and not appealable. Loans, which should not have exceeded $60 \%$ in some cases and $40 \%$ of land valuation in other cases, could have been issued for 13.18 or 28 years from the account of 9 rubles 25 kopecks, 7 rubles 50 kopecks or 5 rubles. 80 kopecks per year from every 100 rubles of credit. In addition, the size of the loan under these "Rules" should not be less than 50 rubles for each individual tenure $[34$, p.46].

In the years following Stolypin's agrarian reform, loans and some financial assistance in the course of land management changed from time to time. Thus, in November 1908, the Ministry of Internal Affairs issued a circular according to which the General Directorate of Land Management and Agriculture had to make adjustments to the existing legal acts of a by-law nature regarding the issuance of loans and the corresponding financial assistance for land management. According to the circular mentioned above, the local administration received the "Summary of the Rules on the Issuance of Loans and Aid for Land Management, approved by the Land Management Committee on March 17, 1907, and supplemented and amended by the Decree No. 153 of October 17, 1908" [37, p. 16-18]. In this "Consolidated Rules" it was emphasized that the corresponding loan or assistance could be satisfied, on the one hand, only "in the case of the usefulness of the proposed costs" and, on the other, "when these costs would be deemed unbearable for the peasants". Some changes also concerned the size of the loan, which, however, should not have exceeded 150 ruble in this case. On all loans issued, the county land management commission undertook to notify the local treasury every three months in order to count the loan as a debt to a particular householder. The loan (which was interest free) was to be repaid in equal installments after 5 granted years over the next ten years. With regard to the grant, it could be provided under the following circumstances: 1) when the land management of these peasants has an exemplary, indicative value for the surrounding residents; 2) if the peasants are in particularly unfavorable conditions and are unable to recover the money received.

In the midst of Stolypin's agrarian changes, the Committee on Land Management Affairs at its meeting on February 20, 1909 approved the so-called "Guidelines", according to which the land purchased by the Peasant Bank in Samara and Saratov provinces, should make its colonial settlement. In addition, the above guidelines recommended that this fund be used exclusively for displaced persons from Volyn, Kyiv, Podolsk and Poltava provinces, as reported to the local state administration and leadership of the Peasant Land Bank [35, p.4-6].

In addition to publications of local state administrations, many official announcements on the form, content and results of agricultural credit, including a small cooperative, are published on the pages of the newspaper "Governmental Gazette", "Gazette of Finance, Industry and Trade", "Herald of Small Credit" and others. central editions. All of them deserve separate analysis in terms of the characteristics of the numerous by-laws of public authorities and public administration. The above also applies to unpublished sources, widely used by Kharkiv jurist V.E. Kirichenko made it possible to thoroughly cover the organizational and legal aspects of the structure of mortgage banks and the features of law enforcement practice [29, p. 38-41].

Conclusions. All of the above gives grounds for concluding that documents of a legal nature, as included in various collections of laws, and those received by the local administration from central authorities in the form of instructions, orders or circulars, are important for 
agricultural loan researchers in the Ukrainian lands of the Russian Empire. Even a cursory analysis of the legislative regulation of agricultural credit in the second half of the nineteenth and early twentieth centuries shows that this trend in the agrarian sphere was not limited to bank credit, because in the years of Stolypin reforms there was a program of crediting direct agricultural producers through management improving the farming conditions of those peasants who created farms and logging, ie consolidated land.

\section{References}

1. Высочайше утвержденное положение Совета Министров: «Об исключении неприятельских подданных из состава членов обществ взаимного кредита и городских кредитных обществ». Собрание узаконений и распоряжений правительства, изданных при Правительствующем Сенате Российской империи. 1915. № 145. Отд. 1. Ст. 1109.

2. Высочайше утвержденное мнение Государственного Совета: «О розрешении учреждениям долгосрочного кредита погашать закладные листы и облигации их как посредством тиражей, так и покупкою на бирже». ПСЗ. Собр. 3-е. Т. XVIII. СПб., 1898. №15494.

3. Высочайше утвержденное мнение Государственного Совета: «О мерах к исправному взносу платежей, следующих Крестьянскому поземельному банку». ПСЗ. Собр. 3-е. Т. IX. СПб., 1889. - №6134.

4. Высочайше утвержденное мнение Государственного Совета: «О порядке совершение крепостных актов на покупку земельных участков, приобретаемых при содействии Крестьянского поземельного банка». ПСЗ. Собр. 3-е. Т. ІІІ. СПб., 1883. №1453.

5. Высочайше утвержденное мнение Государственного Совета: «О порядке продажи и торговли земельных участков, заложенных в Крестьянском поземельном банке». ПСЗ. Собр. 3-е. Т. III. СПб., 1883. №1610.

6. Высочайше утвержденное мнение Государственного Совета: «Об издании правил о крестьянских поземельных товариществах, приобретающих земли с содействия Крестьянского поземельного банка». ПСЗ. Собр. 3-е. Т. VIII. СПб., 1888. №5278.

7. Высочайше утвержденное мнение Государственного Совета: «Об изменении и дополнении существующих новых правил относительно открытия новых акционерных коммерческих банков». ПСЗ. Собр. 3-е. Т. ІІІ. СПб., 1883. № 1484.

8. Высочайше утвержденное мнение Государственного Совета: «Об изменении порядка ревизии государственных кредитных установлений». ПСЗ. Собр. 3-е. Т. XV. СПб., 1895. № 117967.

9. Высочайше утвержденное мнение Государственного Совета: «Об учреждении Государственного дворянского земельного банка». ПСЗ. Собр. 3-е. Т. V. СПб., 1885. № 3016.

10. Высочайше утвержденное мнение Департамента государственной экономии Государственного Совета: «О разрешении Крестьянскому поземельному банку выдачи ссуд для покупки земель не принадлежащих к крестьянскому сословию земледельцам некоторых уездов Херсонской и Подольской губернии». ПСЗ. Собр. 3-е. Т. V. СПб., 1885. № 3016.

11. Высочайше утвержденное положение Кабинета Министров «О мерах к восстановлению деятельностей Харьковского земельного банка». ПСЗ. Собр. 3-е. Т. ХХІІ. СПб., 1902. № 21011.

12. Высочайше утвержденное положение Комитета Министров, объявленное Сенату: «О распространении на заемщиков частных земельных банков льгот, установленных Положением о Государственном дворянском банке». ПСЗ. Собр. 3-е. Т. VI. СПб., 1886. №3668.

13. Высочайше утвержденный Устав Государственного дворянского земельного банка. ПСЗ. Собр. 3-е. Т. Х. СПб., 1890. №6925.

14. Высочайше утвержденный Устав Земского банка Херсонской губернии. ПСЗ. Собр. 2-е Т. XXХІХ. СПб., 1864. №40898.

15. Высочайше утвержденный Устав Киевского земельного банка. ПСЗ. Собр. 2-е. T. XLVII. СПб., 1872. №50714.

16. Высочайше утвержденный Устав Крестьянского поземельного банка. ПСЗ. Собр. 3-е. T. XV. СПб., 1895. №12195.

17. Высочайше утвержденный Устав Общества взаимного поземельного кредита. ПСЗ. Собр. 2-е. Т. XLI. СПб., 1866. №43361.

18. Высочайше утвержденный Устав Общества поземельного кредита. ПСЗ. Собр. 2-е. T. XL. Собр., 1865. №42280. 19. Высочайше утвержденный Устав Полтавского земельного банка. ПС3. Собр. 2-е.- Т. XLVII. СПб., 1872. №50708.

20. Высочайше утвержденный Устав Харьковского земельного банка . ПС3. Собр. 2-е. T. XLVI. СПб., 1871. №49556.

21. Высочайшей указ, данный Правительствующему Сенату: «О понижении платежей заемщиков Крестьянского поземельного банка и об изменении условий выпуска государственных свидетельств названного банка». Собрание узаконений и разпоряжений правительства, изданных при Правительствующем Сенате Российской империи. 1906. №244. Отд. 1. Ст. 1727.

22. Высочайший указ «Об облегчении задачи Крестьянского поземельного банка по содействию к увеличению площади землевладения малоземельных крестьян. Собрание узаконений и распоряжений правительства, изданных при Правительствующем Сенате Российской империи. 1905. №207. Отд. 1. Ст. 1754.

23. Высочайший указ: «О выдаче Крестьянским поземельным банком ссуд под залог надельных земель». ПСЗ. Собр. 3-е.- Т.XXVI. СПб., 1906. №28547. 
24. Головко О. М., Кириченко В. С. Закон у системі права Російської імперії (термін, поняття, категорія). Вісник Харківського національного університету внутрішніх справ. 2009. № 3 (46). C. 34-43.

25. Головко О. М. Правове регулювання діяльності відділень Державного селянського поземельного банку у кінці XIX-на початку XX ст. Науковий вісник Юридичної академії МВС України. 2004. №4. С. 87-93.

26. Дякин В. С. Деньги для сельского хозяйства: Выбор пути экономического розвития России. 1892-1914 гг. История СССР. 1991. № 3. С. 64-84.

27. Именной Высочайший указ: «О выдаче Крестьянским поземельным банком ссуд под залог надельных земель». ПСЗ. Собр. 3-е. Т. XXVI. СПб., 1906. № 28547.

28. Именной Высочайший указ: «О дополнении некоторых постановлений действующего закона, касающихся крестьянского землевладения и землепользования». ПСЗ. Собр. 3-е. Т. XXVI. СПб.,1906. №28528.

29. Кириченко В.С. Установи довгострокового кредиту у Російській імперії в Україні (друга половина XIX-початок XX): історико-правове дослідження: (монографія). Харків: Контраст, 2010. $688 \mathrm{c}$.

30. Корелин А. П. Сельскохозяйственный кредит в Росии в конце XIX-начале XX в.) ; под ред. В. И. Бовыкина (отв. ред.). М. : Наука, 1988. 262 с.

31. Ленін В. І. Аграрна програма соціал-демократії у першій російській революції 19051907 років. Повне зібр. тв. Т. 16. С. 179-386.

32. О дополнении §26 Устава земского банка Херсонской губернии. ПС3. Собр. 2-е. Т. XLIX. СПб., 1874. №53639.

33. Пашенцев Д.А. Правовое регулирование банковской деятельности в Российской империи (вторая половина XIX-начало XX века : дис. канд. юрид. наук: 12.00.01. М., 2005. 171c.

34. Правила выдачи Крестьянским поземельным банком ссуд для улучшения землепользования . Журнал Полтавского губернского присутствия №7 и 8. За июль и август 1907 года. Полтава: Электрич. типо- литогр. Д. Подземского, 1907. С. 42-49.

35. Руководящее указания на 1910 год. Утверждены Комитетом по землеустроительным делам в заседании 20 февраля 1909 года. Журнал Полтавского губернского присутствия. За май 1910 года. Полтава: Электрич. типо-литогр. Д. Подземского, 1910. С. 4-6.

36. Свод законов Российской империи. Том 1. Часть 1. Свод Основных государственных законов. Гл. VIII. Статья 53. СПб., 1832.

37. Свод правил о выдаче ссуд и пособий на землеустройство, утвержденных Комитетом по землеустроительным делам 17 марта 1907 г., и дополненных и измененных постановлением от 17 октября 1908 г. № 153. Журнал Полтавского губернского присутствия №4. За апрель 1909 года. Полтава: Эликтрич. типо-литогр. Д. Подземского, 1909. С. 16-18.

38. Указ министру финансов. «О понижению платежей заемщиков Крестьянского поземельного банка». ПСЗ. Собр. 3-е. Т. XXVIII. СПб.,1898. №16161.

39. Устав кредытный (Св. Зак. Т. ХІ. Ч. 2, изд. 1903 и по Прод. 1912): комментированный законодательными мотивами, розъяснениями правительствующего Сената, правилами, инструкциями и другими распоряжениями, последовавшими в порядке управления / Ю. В. Александровский; [неофиц. изд.]. СПб.: Юрид. изд-во «Закон и Право», 1914. 642 с.

40. Финогентова O.C. Законодательное регулирование банковской деятельности в России: первая половина XVII начало XX вв. : автореф. дис. доктора юрид. наук: 12.00.01. Саратов, 2004. $66 \mathrm{c}$.

Received to editorial office 13.11.2019

1. Vysochayshe utverzhdennoye polozheniye Soveta Ministrov: "Ob isklyuchenii nepriyatel'skikh poddannykh iz sostava chlenov obshchestv vzaimnogo kredita i gorodskikh kreditnykh obshchestv" [The highest approved provision of the Council of Ministers: "On the exclusion of enemy nationals from the membership of mutual credit societies and city credit societies]. Sobraniye uzakoneniy i rasporyazheniy pravitel'stva, izdannykh pri Pravitel'stvuyushchem Senate Rossiyskoy imperii. 1915. № 145. Otd. 1. St. 1109. [in Russ.]

2. Vysochayshe utverzhdennoye mneniye Gosudarstvennogo Soveta: "O rozreshenii uchrezhdeniyam dolgosrochnogo kredita pogashat' zakladnyye listy i obligatsii ikh kak posredstvom tirazhey, tak i pokupkoyu na birzhe" [The highest approved opinion of the State Council: "On allowing longterm credit institutions to repay their mortgage bonds and their bonds both by circulation and by buying on the stock exchange"]. PSZ. Sobr. 3-ye. T. XVIII. SPb., 1898. № 15494. [in Russ.]

3. Vysochayshe utverzhdennoye mneniye Gosudarstvennogo Soveta: "O merakh k ispravnomu vznosu platezhey, sleduyushchikh Krest'yanskomu pozemel'nomu banku" [The highest approved opinion of the State Council: "On measures for the sound payment of payments following the Peasant Land Bank”]. PSZ. Sobr. 3-ye. T. IX. SPb., 1889. - № 6134. [in Russ.]

4. Vysochayshe utverzhdennoye mneniye Gosudarstvennogo Soveta: "O poryadke soversheniye krepostnykh aktov na pokupku zemel'nykh uchastkov, priobretayemykh pri sodeystvii Krest'yanskogo pozemel'nogo banka" [The highest approved opinion of the State Council: "On the procedure for the execution of serf acts for the purchase of land acquired with the assistance of the Peasant Land Bank"]. PSZ. Sobr. 3-ye. T. III. SPb., 1883. №1453. [in Russ.]

5. Vysochayshe utverzhdennoye mneniye Gosudarstvennogo Soveta: «O poryadke prodazhi i torgovli zemel'nykh uchastkov, zalozhennykh v Krest'yanskom pozemel'nom banke» [The highest approved 
opinion of the State Council: "On the procedure for the sale and trade of land plots pledged in the Peasant Land Bank”]. PSZ. Sobr. 3-ye. T. III. SPb., 1883. №1610. [in Russ.]

6. Vysochayshe utverzhdennoye mneniye Gosudarstvennogo Soveta: «Ob izdanii pravil o krest'yanskikh pozemel'nykh tovarishchestvakh, priobretayushchikh zemli s sodeystviya Krest'yanskogo pozemel'nogo banka» [The highest approved opinion of the State Council: "On the publication of the rules on peasant land partnerships acquiring land with the assistance of the Peasant Land Bank"]. PSZ. Sobr. 3-ye. T. VIII. SPb., 1888. №5278. [in Russ.]

7. Vysochayshe utverzhdennoye mneniye Gosudarstvennogo Soveta: "Ob izmenenii i dopolnenii sushchestvuyushchikh novykh pravil otnositel'no otkrytiya novykh aktsionernykh kommercheskikh bankov" [The highest approved opinion of the State Council: "On amending and supplementing the existing new rules regarding the opening of new joint-stock commercial banks"]. PSZ. Sobr. 3-ye. T. III. SPb., 1883. № 1484. [in Russ.]

8. Vysochayshe utverzhdennoye mneniye Gosudarstvennogo Soveta: «Ob izmenenii poryadka revizii gosudarstvennykh kreditnykh ustanovleniy» [The highest approved opinion of the State Council: "On changing the procedure for revising state credit institutions”]. PSZ. Sobr. 3-ye. T. XV. SPb., 1895. № 117967. [in Russ.]

9. Vysochayshe utverzhdennoye mneniye Gosudarstvennogo Soveta: «Ob uchrezhdenii Gosudarstvennogo dvoryanskogo zemel'nogo banka» [The highest approved opinion of the State Council: "On the establishment of the State Noble Land Bank”]. PSZ. Sobr. 3-ye. T. V. SPb., 1885. № 3016. [in Russ.]

10. Vysochayshe utverzhdennoye mneniye Departamenta gosudarstvennoy ekonomii Gosudarstvennogo Soveta: «O razreshenii Krest'yanskomu pozemel'nomu banku vydachi ssud dlya pokupki zemel' ne prinadlezhashchikh k krest'yanskomu sosloviyu zemledel'tsam nekotorykh uyezdov Khersonskoy i Podol'skoy gubernii» [The supremely approved opinion of the Department of State Economy of the State Council: "On allowing the Peasant Land Bank to issue loans for the purchase of land not belonging to the peasant estate to farmers of some counties of the Kherson and Podolsk province"]. PSZ. Sobr. 3-ye. T. V. SPb., 1885. № 3016. [in Russ.]

11. Vysochayshe utverzhdennoye polozheniye Kabineta Ministrov «O merakh k vosstanovleniyu deyatel'nostey Khar'kovskogo zemel'nogo banka» [The highest approved position of the Cabinet of Ministers "On measures to restore the activities of the Kharkov Land Bank"]. PSZ. Sobr. 3-ye. T. XXII. SPb., 1902. № 21011. [in Russ.]

12. Vysochayshe utverzhdennoye polozheniye Komiteta Ministrov, ob"yavlennoye Senatu: «O rasprostranenii na zayemshchikov chastnykh zemel'nykh bankov l'got, ustanovlennykh Polozheniyem o Gosudarstvennom dvoryanskom banke» [The highest approved provision of the Committee of Ministers, announced to the Senate: "On extending to borrowers of private land banks the privileges established by the Regulation on the State Noble Bank”]. PSZ. Sobr. 3-ye. T. VI. SPb., 1886. №3668. [in Russ.]

13. Vysochayshe utverzhdennyy Ustav Gosudarstvennogo dvoryanskogo zemel'nogo banka [The highest approved Charter of the State Noble Land Bank]. PSZ. Sobr. 3-ye. T. X. SPb., 1890. №6925. [in Russ.]

14. Vysochayshe utverzhdennyy Ustav Zemskogo banka Khersonskoy gubernii [The highest approved Charter of the Zemsky Bank of the Kherson province]. PSZ. Sobr. 2-ye T. XXXIX. SPb., 1864. №40898. [in Russ.]

15. Vysochayshe utverzhdennyy Ustav Kiyevskogo zemel'nogo banka [The highest approved Charter of the Kiev Land Bank]. PSZ. Sobr. 2-ye. T. XLVII. SPb., 1872. №50714. [in Russ.]

16. Vysochayshe utverzhdennyy Ustav Krest'yanskogo pozemel'nogo banka [The highest approved Charter of the Peasant Land Bank]. PSZ. Sobr. 3-ye. T. XV. SPb., 1895. №12195.

17. Vysochayshe utverzhdennyy Ustav Obshchestva vzaimnogo pozemel'nogo kredita [The highest approved Articles of Association of the mutual land loan]. PSZ. Sobr. 2-ye. T. XLI. SPb., 1866. №43361. [in Russ.]

18. Vysochayshe utverzhdennyy Ustav Obshchestva pozemel'nogo kredita [The highly approved Charter of the Land Loan Company]. PSZ. Sobr. 2-ye. T. XL. Sobr., 1865. №42280. [in Russ.]

19. Vysochayshe utverzhdennyy Ustav Poltavskogo zemel'nogo banka [The highest approved Charter of the Poltava Land Bank]. PSZ. Sobr. 2-ye.- T. XLVII. SPb., 1872. №50708. [in Russ.]

20. Vysochayshe utverzhdennyy Ustav Khar'kovskogo zemel'nogo banka [The highest approved Charter of the Kharkov Land Bank]. PSZ. Sobr. 2-ye. T. XLVI. SPb., 1871. №49556.

21. Vysochayshey ukaz, dannyy Pravitel'stvuyushchemu Senatu: «O ponizhenii platezhey [in Russ.]zayemshchikov Krest'yanskogo pozemel'nogo banka i ob izmenenii usloviy vypuska gosudarstvennykh svidetel'stv nazvannogo banka» [The highest decree given to the Governing Senate: "On lowering payments by borrowers of the Peasant Land Bank and on changing the conditions for issuing state certificates of the named bank"]. Sobraniye uzakoneniy i razporyazheniy pravitel'stva, izdannykh pri Pravitel'stvuyushchem Senate Rossiyskoy imperii. 1906. №244. Otd. 1. St. 1727. [in Russ.]

22. Vysochayshiy ukaz «Ob oblegchenii zadachi Krest'yanskogo pozemel'nogo banka po sodeystviyu $\mathrm{k}$ uvelicheniyu ploshchadi zemlevladeniya malozemel'nykh krest'yan [The highest decree "On facilitating the task of the Peasant Land Bank to help increase the land tenure of low-land peasants. A collection of legalizations and government orders issued by the Governing Senate of the Russian Empire]. Sobraniye uzakoneniy i rasporyazheniy pravitel'stva, izdannykh pri Pravitel'stvuyushchem Senate Rossiyskoy imperii. 1905. №207. Otd. 1. St. 1754. [in Russ.]

23. Vysochayshiy ukaz: «O vydache Krest'yanskim pozemel'nym bankom ssud pod zalog nadel'nykh zemel'» [The highest decree: "On the granting by the Peasant Land Bank of loans secured by allotment lands”]. PSZ. Sobr. 3-ye. - T. XXVI. SPb., 1906. №28547. [in Russ.] 
24. Holovko, O. M., Kyrychenko. V. Ye. (2009) Zakon u systemí prava Rosíys'koyi ímperíyi (termín, ponyattya, kategoríya) [The law of the system of law of the Russian Federation (terminology, understanding, category)]. Vísnik Kharkivs'kogo natsional'nogo uníversitetu vnutríshníkh sprav. № 3 (46). S. 34-43. [in Ukr.]

25. Holovko, O. M. (2004) Pravove regulyuvannya díyal'ností víddílen' Derzhavnoho selyans'koho pozemel'noho banku u kíntsí KHÍKH-na pochatku KHKH st. [Legal regulation of the sovereign peasant land bank at the end of XIX - on the cob of the 20th century] Naukovyy vísnyk Yurydychnoyí akademiïy MVS Ukrayïny. №4. S. 87-93. [in Ukr.]

26. Dyakin, V. S. (1991) Den'gi dlya sel'skogo khozyaystva: Vybor puti ekonomicheskogo rozvitiya Rossii. 1892-1914 gg. [Money for agriculture: Choosing the path of economic development of Russia. 1892-1914] Istoriya SSSR. № 3. S. 64-84. [in Russ.]

27. Imennoy Vysochayshiy ukaz: «O vydache Krest'yanskim pozemel'nym bankom ssud pod zalog nadel'nykh zemel'» [Personal Highest Decree: "On the granting by the Peasant Land Bank of loans secured by allotment lands”]. PSZ. Sobr. 3-ye. T. XXVI. SPb., 1906. № 28547. [in Russ.]

28. Imennoy Vysochayshiy ukaz: «O dopolnenii nekotorykh postanovleniy deystvuyushchego zakona, kasayushchikhsya krest'yanskogo zemlevladeniya i zemlepol'zovaniya» [Personal Highest Decree: "On the Supplement of Certain Resolutions of the Current Law Relating to Peasant Land Ownership and Land Use"]. PSZ. Sobr. 3-ye. T. XXVI. SPb.,1906. №28528. [in Russ.]

29. Kyrychenko, V. Ye. (2010) Ustanovy dovhostrokovoho kredyu u Rosíys'kíy ímperíyi v Ukrayiní (druha polovyna XIX - pochatok XX): ístoryko-pravove doslídzhennya: (monohrafíya) [Set a pre-contract loan with the Russian Federation in Ukraine (second half XIX - beginning of XX): historical and legal law:]. Kharkív: Kontrast,. 688 s. [in Ukr.]

30. Korelin, A. P. (1988) Sel'skokhozyaystvennyy kredit v Rosii v kontse XIX - nachale XX v.) [Agricultural credit in Russia at the end of the 19th - beginning of the 20th centuries)]; pod red. V. I. Bovykina (otv. red.). M. : Nauka,. 262 s. [in Russ.]

31. Lenín V. Í. Agrarna programa sotsíal-demokratî̈ u pershíy rosíys'kíy revolyutsîi 1905-1907 rokív [Agrarian program of social democracy at the first Russian Revolution of 1905-1907]. Povne zíbr. tv. T. 16. S. 179-386. [in Russ.]

32. O dopolnenii $\$ 26$ Ustava zemskogo banka Khersonskoy gubernii [On amendment of $\$ 26$ of the Charter of the Zemsky bank of the Kherson province]. PSZ. Sobr. 2-ye. T. XLIX. SPb., 1874. №53639. [in Russ.]

33. Pashentsev D.A. Pravovoye regulirovaniye bankovskoy deyatel'nosti v Rossiyskoy imperii (vtoraya polovina XIX - nachalo XX veka) [Legal regulation of banking in the Russian Empire (second half of the 19th - beginning of the 20th centuries]: dis. kand. yurid. nauk: 12.00.01. M., 2005. 171 s. [in Russ.]

34. Pravila vydachi Krest'yanskim pozemel'nym bankom ssud dlya uluchsheniya zemlepol'zovaniya [Rules for granting loans by the Peasant Land Bank to improve land use]. Zhurnal Poltavskogo gubernskogo prisutstviya №7 i 8. Za iyul' i avgust 1907 goda. Poltava: Elektrich. tipo- litogr. D. Podzemskogo, 1907. S. 42-49. [in Russ.]

35. Rukovodyashcheye ukazaniya na 1910 god [Guideline for 1910]. Utverzhdeny Komitetom po zemleustroitel'nym delam v zasedanii 20 fevralya 1909 goda. Zhurnal Poltavskogo gubernskogo prisutstviya. Za may 1910 goda. Poltava: Elektrich. tipo-litogr. D. Podzemskogo, 1910. S. 4-6. [in Russ.]

36. Svod zakonov Rossiyskoy imperii [Code of laws of the Russian Empire]. Tom 1. Chast' 1. Svod Osnovnykh gosudarstvennykh zakonov. Gl. VIII. Stat'ya 53. SPb., 1832. [in Russ.]

37. Svod pravil o vydache ssud i posobiy na zemleustroystvo [The set of rules on the issuance of loans and grants for land management], utverzhdennykh Komitetom po zemleustroitel'nym delam 17 marta 1907 g., i dopolnennykh i izmenennykh postanovleniyem ot 17 oktyabrya 1908 g. № 153 . Zhurnal Poltavskogo gubernskogo prisutstviya №4. Za aprel' 1909 goda. Poltava: Eliktrich. tipo-litogr. D. Podzemskogo, 1909. S. 16-18. [in Russ.]

38. Ukaz ministru finansov «O ponizheniyu platezhey zayemshchikov Krest'yanskogo pozemel'nogo banka» [Decree to the Minister of Finance. "On the reduction of payments of borrowers of the Peasant Land Bank"]. PSZ. Sobr. 3-ye. T. XXVIII. SPb.,1898. №16161. [in Russ.]

39. Ustav kredytnyy ([Credit charter: commented on legislative motives, clarifications of the governing Senate, rules, instructions and other orders that followed in the management order] Sv. Zak. T. XI. Ch. 2, izd. 1903 i po Prod. 1912): kommentirovannyy zakonodatel'nymi motivami, roz"yasneniyami pravitel'stvuyushchego Senata, pravilami, instruktsiyami i drugimi rasporyazheniyami, posledovavshimi $\mathrm{v}$ poryadke upravleniya / Yu. V. Aleksandrovskiy; [neofits. izd.]. SPb.: Yurid. izd-vo «Zakon i Pravo», 1914. 642 s. [in Russ.]

40. Finogentova O.Ê. Zakonodatel'noye regulirovaniye bankovskoy deyatel'nosti v Rossii: pervaya polovina XVII nachalo XX vv. [Legislative regulation of banking in Russia: the first half of the 17th and early 20th centuries]: avtoref. dis. doktora yurid. nauk: 12.00.01. Saratov, 2004. $66 \mathrm{~s}$. [in Russ.]

\section{Summary}

The agrarian sector of modern Ukraine is at the stage of its reform, when the process of regulating public relations in the field of production and marketing of agricultural products at the legislative level is close to its logical conclusion, since the overwhelming majority of deputies of the Verkhovna Rada of Ukraine is determined to adopt the law on the circulation of agricultural land in the end, which should open a new page for the development of the domestic agricultural market. From this point of view, not only theoretical but also practical interest are raised by issues related to the study of 
the historical experience of legislative regulation of the mortgage loan, which took place in our country after the abolition of serfdom in 1861 and other reforms of the agrarian sector of the Ukrainian economy in the second half of nineteenth and early twentieth centuries. The main focus of this publication is on the analysis of credit law in its various forms, which have occurred in the period under study. We mean the various "Decrees", "Regulations", "Rules", "Dumkas", "Instructions", etc. Paying attention to the fact that the central axis of the land loan at the turn of the nineteenth and twentieth centuries was legislation on the activity of state banks, of course, that they (Peasant Land and Noble Land Bank) became the subject of the author's close attention. Hence the characterization of such legal acts as "On the procedure for sale by auction of land pledged in the Peasant Land Bank", "On permitting the Peasant Land Bank to issue loans for the purchase of land not belonging to the peasant state by landowners of some Kherson and Podilsky districts" , "On approval of the State Noble Land Bank", "On the extension to the borrowers of private land banks of privileges established by the Regulations on the State Noble Land Bank", etc. In addition to the above-mentioned legal acts, which are concentrated mainly in the "Full Assembly of Laws of the Russian Empire" (second and third editions), the article also mentions such sources on the content and form of agricultural credit of 1861-1917, as the newspaper "Government Gazette", and the journals "Gazette of Finance, Industry and Trade", "Bulletin of the Small Credit", which reflect practical measures for the implementation of certain legislative acts and the role in this process of local state administrations and zemstvos.

Keywords: Russian Empire, Ukraine, legislation, agricultural credit.

UDC 340

DOI: $10.31733 / 2078-3566-2019-5-113-118$

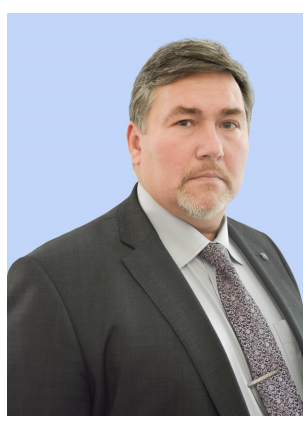

Oleksandr TALDYKIN ${ }^{\odot}$

Ph.D, Ass. Prof.

(Dnipropetrovsk State University

of Internal Affairs)

\section{THE VOIVODSHIP SYSTEM IN THE $17^{\text {th }}$ CENTURY ON THE LANDS OF UKRAINE}

Олександр Талдикін. ВОСВОДСЬКІ ВІДДІЛИ У 17 СТОЛІТТІ НА ЗЕМЛЯХ УКРАЇнИ. Розглянуто появу воєвод та території земель України. Першими адміністративнополіцейськими органами російської держави на території України були канцелярії російських воєводських управлінь.

Поява воєвод на землях України відбувається протягом другої половини XVII ст. Поліцейські функції воєводи, разом із військовими, судовими та фінансовими, були основними напрямками їх діяльності. Наскільки інтенсивно воєводи діяли 3 питань адміністративнополіцейських, сказати однозначно не можна. 3 одного боку, їм належали поліція, суд і розправа над підлеглими стрільцями, великоросійськими робочими людьми, 3 іншого, їх втручання в поліцію і суд серед місцевого населення, хоч воно й було обмежено, але не було епізодичним.

Воєводсько-наказова система управління була чітко централізованою. Це означало не тільки суворе підпорядкування воєводи Москві, але і обмеження його повноважень виконанням розпоряджень, інструкцій i наказів центральної влади, а також, передбачало наявність необхідності багато в чому узгоджувати свою діяльність з Розрядним і іншими Приказами. Зміна воєвод була частою, через два, два 3 половиною роки, що, як вважалося, що не дозволяло їм "засиджуватися" і зловживати своєю владою з корисливих мотивів.

Загальна поліцейська діяльність воєвод Слобідської України регламентувалася чинними законодавчими актами Російської держави, а також інструкціями і указами, різноманітними $\mathrm{i}$ багато в чому суперечливими. Відсутність чіткого нормативного оформлення поліцейських функцій часто призводило до управління за принципом "як бог надоумить". Воєводи були зобов'язані стежити за порядком, організовувати його охорону, пропускний режим в містах, що виключає можливість, як проникнення шпигунів, так i осідання в них селян-кріпаків, які підлягають розшуку i відсиланню володарям. Крім того, воєводи контролювали стан продовольства і будов, вживали заходів проти поширення епідемій і пожеж

Нормативне регулювання діяльності поліції воєводи визначалося: діючими законодавчими актами Російської держави, договорами гетьмана і Росії, а також прямими указами царя та Приказів.

(C) Taldykin O., 2019

ORCID iD: https://orcid.org/0000-0001-8681-5523

alextall14@gmail.com 